\title{
Assessment of ileal digestibility of lupin amino acids and their use in formulating diets for pigs ${ }^{*}$
}

\author{
Justyna Wasilewko ${ }^{1}$, Jolanta Gdala' ${ }^{1}$, Lucyna Buraczewska ${ }^{1}$ \\ and In K. Han ${ }^{2}$
}

\author{
'The Kielanowski Institute of Animal Physiology and Nutrition, \\ Polish Academy of Sciences \\ 05-110 Jablonna, Poland \\ 'Department of Animal Science and Technology, \\ College of Agriculture and Life Science, Seoul National University \\ Suweon 441-744, Korea
}

(Received 16 September 1998; accepted 19 November 1998)

\begin{abstract}
The apparent and true ileal digestibility of protein and amino acids of five yellow lupin cultivars grown in Poland was estimated on growing castrated male pigs. The nitrogen retention was determined on young boars fed a barley-yellow lupin diet supplemented with crystalline lysine, methionine and tryptophan.

The apparent ileal digestibility of the seed protein was from 81.9 to $84.9 \%$. There were no significant differences in protein or in amino acid apparent digestibility among the yellow lupin cultivars. The true ileal digestibility of crude protein was from 87.5 to $90.5 \%$. Nitrogen retention was significantly lower $(\mathrm{P}<0.05)$ in pigs fed the diet supplemented with amino acids according to pig requirements for total amino acids (methionine constituted $36 \%$ of the sulphur containing amino acids) than in those fed the same diet but with higher methionine content (50\% of sulphur containing amino acids) or the diet supplemented according to the requirements for ileal digestible amino acids.
\end{abstract}

KEY WORDS: yellow lupin seeds, ileal digestibility, nutritive value, pigs

* This study partially funded by Ministry of Agriculture and Forestry, Special Grant Research Program in Korea 


\section{INTRODUCTION}

Yellow lupin seeds (Lupinus luteus L.) may contain up to $480 \mathrm{~g} / \mathrm{kg} \mathrm{DM}$ of crude protein. Lupin protein is deficient in methionine and has too low level of both lysine and tryptophan to be a good supplement to cereals in pig rations (Eggum et al., 1993). Therefore, cereal-lupin diets have to be enriched with high value protein products and/or synthetic amino acids to meet pig requirement for lysine, methionine and tryptophan.

A modern pig feeding system should consider a diet formulation on an amino acid availability basis. It seems that at present the best approximation to the available amino acid content in feed is by ileal amino acid digestibility. There is a limited information on ileal digestibility of protein and amino acids of seeds of different lupin species. Some available data show that the true ileal digestibility of protein of narrow leaved lupins range from 86 to $90 \%$ (Maillard et al., 1990; Rhodimet Nutrition Guide, 1993). Yellow lupin cultivars are less extensively grown than narrow leaved ones and there are not much data on their protein ileal digestibility.

The aim of the present study was to determine the apparent and true ileal digestibility of seed protein and amino acids of five yellow lupin cultivars cultivated in Poland and the nitrogen retention in pigs fed a barley-yellow lupin diet supplemented with lysine, methionine and tryptophan.

\section{MATERIAL AND METHODS}

\section{Lupin}

Seeds of five varieties of yellow lupin (Polonez', Radames, Manru, Popiel, Juno) were purchased in 1991 and 1992 from Polish Plant Breeding Stations located in the central and middle-west regions of the country. Lupins were cultivated in standarized soil conditions.

\section{Digestibility experiment}

Animals and diets. Two groups, one of six and another of eight castrated crossbred male pigs were used in the digestibility study. The average initial and final body weight of animals was about 13 and $34 \mathrm{~kg}$, respectively. Pigs were fitted with a post valve T-caecum (PVTC) cannula (van Leeuwen et al., 1991).

\footnotetext{
${ }^{1}$ Recently, this variety was withdrawn and the name Polonez was given to a new variety of narrow leaved lupin
} 
TABLE 1

Chemical composition of lupin seeds, g/kg DM

\begin{tabular}{|c|c|c|c|c|c|}
\hline \multirow{3}{*}{$\begin{array}{c}\text { Indices } \\
\text { Year of harvest }\end{array}$} & \multicolumn{5}{|c|}{ L. luteus } \\
\hline & Popiel & Juno & Polonez & Radames & Manru \\
\hline & \multicolumn{2}{|c|}{1991} & \multicolumn{3}{|c|}{1992} \\
\hline Weight of 1000 seeds, g & 132 & 131 & 116 & 137 & 108 \\
\hline Dry matter, $\%$ & 88.3 & 88.7 & 88.7 & 88.6 & 90.0 \\
\hline $\mathrm{N} \times 6.25$ & 443 & 441 & 438 & 422 & 423 \\
\hline Crude fat & 53 & 52 & 47 & 57 & 55 \\
\hline Crude ash & 51 & 52 & 45 & 57 & 53 \\
\hline Crude fibre & 136 & 143 & 162 & 166 & 173 \\
\hline \multicolumn{6}{|l|}{ Fibre fractions } \\
\hline NDF & 216 & 234 & 252 & 259 & 268 \\
\hline $\mathrm{ADF}$ & 200 & 194 & 204 & 217 & 217 \\
\hline ADL & 16 & 27 & 31 & 22 & 28 \\
\hline Alkaloids, $\mathrm{mg} / \mathrm{kg}$ & 1300 & 230 & - & - & - \\
\hline $\mathrm{Mn}, \mathrm{mg} / \mathrm{kg}$ & 120 & 34 & 39 & 71 & 85 \\
\hline
\end{tabular}

TABLE 2

The content of essential amino acids and cystine in lupins, $\mathrm{g} / 16 \mathrm{~g} \mathrm{~N}$

\begin{tabular}{|c|c|c|c|c|c|}
\hline \multirow{3}{*}{$\begin{array}{c}\text { Indices } \\
\text { Year of harvest }\end{array}$} & \multicolumn{5}{|c|}{ L. luteus } \\
\hline & Popiel & Juno & Polonez & Radames & Manru \\
\hline & \multicolumn{2}{|c|}{1991} & \multicolumn{3}{|c|}{1992} \\
\hline Lys & 5.02 & 5.10 & 5.12 & 4.95 & 5.11 \\
\hline Met & 0.79 & 0.80 & 0.89 & 0.84 & 0.94 \\
\hline Cys & 2.07 & 2.11 & 2.12 & 2.34 & 2.14 \\
\hline Thr & 3.17 & 3.19 & 3.27 & 3.13 & 3.33 \\
\hline $\operatorname{Trp}$ & 0.78 & 0.78 & 0.95 & 0.94 & 0.82 \\
\hline Ile & 3.83 & 3.92 & 3.78 & 3.68 & 3.67 \\
\hline Arg & 11.02 & 11.51 & 11.15 & 10.27 & 10.80 \\
\hline His & 2.71 & 2.67 & 2.81 & 2.58 & 2.70 \\
\hline Leu & 7.66 & 7.80 & 7.68 & 7.73 & 7.54 \\
\hline Phe & 3.64 & 3.71 & 4.30 & 3.96 & 3.95 \\
\hline Val & 3.63 & 3.76 & 3.63 & 3.52 & 3.62 \\
\hline
\end{tabular}

After 10 days of recovery, the animals were placed in metabolism cages. The pigs were fed the experimental diets (Table 3) for at least seven day period in a changed-over design. Each diet was offered to two pigs twice a day at 08:00 and 20:00 $\mathrm{h}$ in a mash form during three experimental periods. A daily amount of feed given to pigs was equal to three times their assumed maintenance requirement for metabolisable energy (1.5 MJ ME/kg BW $\left.{ }^{0.75}\right)$. 
TABLE 3

Composition of lupin-casein and casein diets, $\mathrm{g} / \mathrm{kg}$ (digestibility experiment)

\begin{tabular}{|c|c|c|c|c|c|c|c|}
\hline \multirow{3}{*}{ Ingredients } & \multicolumn{7}{|c|}{ Diets } \\
\hline & \multicolumn{5}{|c|}{ lupin-casein with } & \multicolumn{2}{|c|}{ casein' } \\
\hline & Polonez & Radames & Manru & Popiel & Juno & 50 & 150 \\
\hline Lupin & 309 & 329 & 315 & 307 & 307 & - & - \\
\hline Casein & 61 & 61 & 61 & 62 & 62 & 61 & 182 \\
\hline Maize starch & 484 & 464 & 478 & 485 & 485 & 818 & 697 \\
\hline Sugar & 80 & 80 & 80 & 80 & 80 & 30 & 30 \\
\hline Soyabean oil & 20 & 20 & 20 & 20 & 20 & 10 & 10 \\
\hline Cellulose & - & - & - & - & - & 30 & 30 \\
\hline Polfamix $\mathrm{P}^{2}$ & 10 & 10 & 10 & 10 & 10 & 10 & 10 \\
\hline Limestone & 10 & 10 & 10 & 10 & 10 & 10 & 10 \\
\hline Phosphorate & 20 & 20 & 20 & 20 & 20 & 25 & 25 \\
\hline $\mathrm{NaCl}$ & 3 & 3 & 3 & 3 & 3 & 3 & 3 \\
\hline $\mathrm{Cr}_{2} \mathrm{O}_{3}$ & 3 & 3 & 3 & 3 & 3 & 3 & 3 \\
\hline Crude protein ${ }^{3}$ & 170 & 170 & 170 & 170 & 170 & 50 & 150 \\
\hline $\mathrm{ME}, \mathrm{MJ} / \mathrm{kg}^{3}$ & 15.2 & 15.2 & 15.2 & 15.2 & 15.2 & 16.7 & 16.7 \\
\hline
\end{tabular}

1 - casein diets contained 50 or $150 \mathrm{~g} / \mathrm{kg}$ of crude protein

${ }^{2}$ - Polfamix P contained per 1 kg: Olaquindox 8 g; Vit. A 1000000 j.m.; Vit. D, 300000 j.m.; Vit. E $1.0 \mathrm{~g}$; Vit.K $0.5 \mathrm{~g}$; Vit. $\mathrm{B}_{1} 0.5 \mathrm{~g}$; Vit. $\mathrm{B}_{2} 1.5 \mathrm{~g}$; Vit.B $0.5 \mathrm{~g}$; Vit. $\mathrm{B}_{12} 4.5 \mathrm{mg}$; Vit.C $10.0 \mathrm{~g}$; folic acid $0.1 \mathrm{~g}$; nicotinic acid $8.0 \mathrm{~g}$; calcium pantothenian $4.0 \mathrm{~g}$; Mn $3.0 \mathrm{~g} ; \mathrm{Fe} 3.0 \mathrm{~g} ; \mathrm{Zn} 3.0 \mathrm{~g} ; \mathrm{Cu} 0.25 \mathrm{~g}$; $\mathrm{J}_{2} 0.1 \mathrm{~g} ; \mathrm{Co} 0.1 \mathrm{~g}$

3 - calculated value

The lupin - casein diets (LCD) were formulated to contain $120 \mathrm{~g}$ lupin and $50 \mathrm{~g}$ casein protein per $\mathrm{kg}$ of the diet. The casein diets containing $50 \mathrm{or} 150 \mathrm{~g}$ of protein were used to estimate apparent and true ileal digestibilities of lupin seeds by difference method.

Digesta collection. After seven days of pig adaptation to lupin or casein diets ileal digesta were collected for 3 days through $12 \mathrm{~h}$ a day $(08: 00-20: 00)$ in plastic bags attached to the cannula. The bags were changed every hour and their contents were immediately frozen in plastic containers at $-20^{\circ} \mathrm{C}$. After completion of the collections, samples were thawed, pooled per animal within each experimental period, freeze-dried and ground before chemical analysis.

Analytical procedures. The seeds, diets and freeze-dried samples of digesta were analysed for the content of crude protein and amino acids. Nitrogen was analysed using standard method (AOAC, 1990). Amino acid analyses were performed with Beckman $6300 \mathrm{High}$ Pressure Amino Acid Analyzer using modified 
procedures described by Buraczewska and Buraczewski (1984). The contents of neutral detergent fibre (NDF), acid detergent fibre (ADF) and acid detergent lignin (ADL) were determined according to the Van Soest and Wine (1967) and Van Soest (1973) methods. The quinolizidine alkaloid content was analysed according to Wysocka et al. (1989) using thin layer chromatography. The manganese was analysed using a Philips PU $9100 \mathrm{X}$ atomic absorption spectrometer (Philips Scientific 1988).

Calculations and statistical analysis. The apparent and the true ileal digestibilities of crude protein and amino acids of lupin seeds were calculated by difference method using the digestibility values of the casein diets.

The apparent ileal digestibility of protein (ADP) of lupin seeds was calculated, using the casein diet with $15 \%$ protein level, according to the formula:

$\operatorname{ADP}(\%)=\frac{\text { ADP of LCD }-\frac{\text { ADP of casein diet } x \text { casein protein } \%}{100}}{\frac{\% \text { of protein of lupin seeds }}{1}}$

where:

${ }^{1}$ - casein protein expresses its proportion in total protein of the LCD assumed as 100

The apparent digestibility of amino acids was calculated using the same formula. The true ileal digestibility (TD) of protein or amino acids in lupin seeds was calculated as follows:

$\mathrm{TD}(\%)=\frac{\text { intake of protein / AA (A) }- \text { amount of undigested protein / AA (B) }}{\text { intake of protein / AA }} \times 100$

where:

$\mathrm{A}$ - intake of protein (each amino acid) of lupin seeds in $1 \mathrm{~kg}$ of lupin-casein diet $\mathrm{B}$ - amount of undigested protein (each amino acid), originating from lupin seeds, calculated as a difference between the amount of undigested protein (each amino acid) after feeding $1 \mathrm{~kg} \mathrm{LCD}$ and $1 \mathrm{~kg}$ casein diet containing $5 \%$ crude protein.

One-way analysis of variance was carried out on the experimental results using a variety of lupin as an independent variable. The significance of differences among 
means was tested with the Tukey range test. All calculations were performed using Statgraphics Plus ver. 7.0 (1993).

\section{Balance experiment}

Animals and diets. The change-over design experiment was performed on 12 crossbred male pigs with the initial body weight of about $30 \mathrm{~kg}$, divided into 3 groups of 4 . The average final weight of animals was $67 \mathrm{~kg}$. Pigs were fed three barley-lupin diets differing in essential amino acid content. The diets $\mathrm{A}, \mathrm{B}$ and $\mathrm{C}$ (Table 4) contained per kg $650 \mathrm{~g}$ of barley and $250 \mathrm{~g}$ of yellow lupin seeds (Polonez and Radames were mixed in a 1:1 proportion); the crude protein content was $160 \mathrm{~g} / \mathrm{kg}$.

TABLE 4

Composition of diets and energy and amino acid contents, $\mathrm{g} / \mathrm{kg}$ (balance experiment)

\begin{tabular}{lccc}
\hline & \multicolumn{3}{c}{ Diet } \\
\cline { 2 - 4 } Indices & $\mathrm{A}$ & $\mathrm{B}$ & $\mathrm{C}$ \\
\hline Barley meal & 650 & 650 & 650 \\
Yellow lupin meal & 250 & 250 & 250 \\
Maize starch & 57 & 56 & 54 \\
Soya oil & 10 & 10 & 10 \\
Limestone & 7 & 7 & 7 \\
Polfamix P & 20 & 20 & 20 \\
Salt & 3 & 3 & 3 \\
L-lysine & 2.37 & 2.37 & 2.77 \\
L-threonine & 0.89 & 0.89 & 1.23 \\
L-tryptophan & 0.05 & 0.05 & 0.24 \\
DL-methionine & - & 0.98 & 1.16 \\
Crude protein & 160 & 160 & 160 \\
ME, MJ/kg (calculated) & 12.6 & 12.6 & 0.79 \\
Total lysine, g/MJ ME & 0.76 & 0.76 & 0.66 \\
Apparent digestible lysine, g/MJ ME & 0.63 & 0.63 & 32 \\
Total Met /Total Lys, \% & 21 & 31.5 & \\
\hline
\end{tabular}

Diet A was supplemented with lysine, threonine, and tryptophan to meet the requirement of male pigs for total amino acids (Nutrient Requirements of Pigs, 1993). The lysine to metabolisable energy ratio was $0.76 \mathrm{~g} / 1 \mathrm{MJ}$ EM. The ratio to lysine for methionine plus cystine was -0.63 , for threonine -0.62 , for tryptophan -0.18 . The sum of methionine and cystine fulfilled the pig requirement for sulphur-containing amino acids, but methionine constituted only $36 \%$ of the sum of the sulphur amino acids. The ratio of methionine to lysine was 0.21 . Diet B was 
supplemented with lysine, threonine and tryptophan up to the same level as diet A, but methionine was added at a higher proportion to constitute $50 \%$ of the required sulphur-containing amino acids. The ratio of methionine to lysine increased up to 0.32 . Diet $\mathrm{C}$ was supplemented with lysine, threonine, tryptophan and methionine to meet male pig requirements for digestible amino acids. The requirement was calculated using values for total amino acid requirement and digestibility coefficients of wheat and soyabean meal adopted from the study of van Leeuwen et al (1993). Methionine constituted $50 \%$ of the sum of sulphur-containing amino acids.

The animals were fed diets twice a day. Each ration was mixed with water. The amount of feed offered to each pig was at the level of 3 times its maintenance requirement for the metabolisable energy (ARC, 1981).

Experimental procedure. After 7 days of adaptation to metabolism cages, pigs were randomly divided into 3 groups ( 4 animals each). Pigs were fed the experimental diets according to a cross-over design for 14 days during 3 experimental periods. Each period comprised 9 days of the preliminary period and 5 days of the urine and faeces collection. Urine was stored at $4^{\circ} \mathrm{C}$ and a pooled sample of urine of each pig was used for analysis. Faeces were kept at $-20^{\circ} \mathrm{C}$ until analysed.

Analytical procedures. Samples of diets, faeces and urine were analysed for the nitrogen content according to the standard procedure (AOAC, 1990).

Calculations and statistical analysis. Based on nitrogen intake values, nitrogen excretion in urine and faeces, nitrogen utilization was calculated.

One-way analysis of variance was carried out on the experimental results using treatment as an independent variable. The significance of differences between means was tested with the least significance difference test (Snedecor and Corchan, 1980). All calculations were performed using the Statgraphics ver. 7.0 (1993) software.

\section{RESULTS}

\section{Chemical composition of lupin seeds}

Seeds contained from 422 to $443 \mathrm{~g} / \mathrm{kg}$ DM of crude protein that was characterized by low methionine $(0.79-0.94 \mathrm{~g} / 16 \mathrm{~g} \mathrm{~N})$ and tryptophan $(0.78-0.95 \mathrm{~g} / 16 \mathrm{~g} \mathrm{~N})$ contents. Lysine content ranged from 4.95 to $5.12 \mathrm{~g} / 16 \mathrm{~g} \mathrm{~N}$ (Tables 1 and 2). Crude fat, ash, and crude fibre amounted up to 57,57 , and $173.0 \mathrm{~g}$ per $\mathrm{kg}$ seed DM, respectively. Among fibre fractions, NDF, ADF, and ADL constituted from 216 to 
$268 \mathrm{~g}, 194$ to $217 \mathrm{~g}$, and from 16 to $31 \mathrm{~g} / \mathrm{kg} \mathrm{DM}$, respectively. In yellow lupin seeds, the level of manganese was from 34 to $120 \mathrm{mg} / \mathrm{kg}$ DM. The total content of alkaloids was determined in seeds of two lupin cultivars and was much higher in Popiel (1300 mg/kg DM) than in Juno (230 mg/ $\mathrm{kg} \mathrm{DM})$.

\section{Digestibility experiment}

The apparent ileal digestibility of the seed protein was from 81.9 to $84.9 \%$ (Table 5). The digestibility of most amino acids was above $80 \%$. Lower digestibility was found only for tryptophan (72.0-75.9\%) and threonine (74.4-76.3\%). There were no significant differences in protein as well as in amino acid digestibility among the tested yellow lupin cultivars.

TABLE 5

Apparent ileal digestibility of protein and amino acids of yellow lupin seeds, $\%$

\begin{tabular}{lcccccccc}
\hline & \multicolumn{9}{c}{ L. luteus } & & \multirow{2}{*}{ Mean } & SEM & P $<$ \\
\cline { 2 - 6 } Indices & Polonez & Radames & Manru & Popiel & Juno & & & \\
\hline N x 6.25 & 84.6 & 84.9 & 84.6 & 81.9 & 82.3 & 83.7 & 0.64 & 0.20 \\
Amino acids & & & & & & & & \\
Lys & 84.9 & 86.4 & 85.8 & 81.8 & 82.9 & 84.4 & 0.87 & 0.09 \\
Met & 83.8 & 79.4 & 81.7 & 78.9 & 79.1 & 80.6 & 0.65 & 0.32 \\
Cys & 83.7 & 84.9 & 83.0 & 82.2 & 82.9 & 83.3 & 0.46 & 0.52 \\
Thr & 74.7 & 76.3 & 76.2 & 74.4 & 74.5 & 75.2 & 0.42 & 0.90 \\
Trp & 72.0 & 72.7 & 73.9 & 75.9 & 75.8 & 74.1 & 0.79 & 0.45 \\
Ile & 85.1 & 85.5 & 84.9 & 84.1 & 73.5 & 82.6 & 0.36 & 0.84 \\
Arg & 93.2 & 93.2 & 93.1 & 92.0 & 92.0 & 92.7 & 0.28 & 0.44 \\
His & 87.2 & 87.8 & 87.3 & 85.4 & 85.5 & 86.6 & 0.50 & 0.28 \\
Leu & 85.3 & 86.8 & 85.5 & 83.4 & 83.9 & 85.0 & 0.56 & 0.36 \\
Phe & 82.2 & 83.1 & 81.4 & 79.4 & 79.3 & 81.1 & 0.75 & 0.14 \\
Val & 78.8 & 79.7 & 79.0 & 79.3 & 79.3 & 79.2 & 0.14 & 0.89 \\
\hline
\end{tabular}

A positive correlation was found between the content and digestibility of the following amino acids: threonine $(r=0.972 ; \mathrm{P}<0.01)$, cystine $(\mathrm{r}=0.984 ; \mathrm{P}<0.01)$, and methionine $(\mathrm{r}=0.943 ; \mathrm{P}<0.01)$. A negative effect was observed between the NDF content and the apparent ileal digestibility of isoleucine $(r=-0.975 ; \mathrm{P}<0.01)$.

The true ileal digestibility of protein was higher than the apparent digestibility and ranged from 87.5 to $90.5 \%$ (Table 6 ). Among the tested yellow lupin cultivars, seeds of lupin Radames had the highest digestibility of crude protein, lysine, cystine, threonine and isoleucine. 
TABLE 6

True ileal digestibility of protein and amino acids of yellow lupin seeds, $\%$

\begin{tabular}{lccccccc}
\hline & \multicolumn{5}{c}{ L. luteus } & \multirow{2}{*}{ Mean } & SD \\
\cline { 2 - 6 } Indices & Polonez & Radames & Manru & Popiel & Juno & & \\
\hline N x 6.25 & 89.5 & 90.5 & 89.5 & 87.5 & 88.0 & 89.0 & 1.22 \\
Amino acids & & & & & & & \\
Lys & 88.4 & 90.1 & 89.9 & 86.6 & 87.7 & 88.5 & 1.48 \\
Met & 87.4 & 85.1 & 86.2 & 84.2 & 85.9 & 85.8 & 1.20 \\
Cys & 87.2 & 88.8 & 86.6 & 86.8 & 87.2 & 87.3 & 0.78 \\
Thr & 83.4 & 85.9 & 84.3 & 83.9 & 84.4 & 84.4 & 0.94 \\
Trp & 79.5 & 80.7 & 82.6 & 87.9 & 85.2 & 83.2 & 3.41 \\
Ile & 88.2 & 89.3 & 88.3 & 87.8 & 87.6 & 88.2 & 0.66 \\
\hline
\end{tabular}

\section{Balance experiment}

The total digestibility of protein of barley-lupin diets was in the range from 82.3 to $83.9 \%$. Nitrogen retention, expressed as a percentage of either of nitrogen intake or nitrogen digested, was significantly lower $(\mathrm{P}<0.05)$ for pigs fed diet $\mathrm{A}$ (40.5 and $49.2 \%$, respectively) than for those fed diet B (49.7 and 59.2\%, respectively) or diet $\mathrm{C}$ (51.5 and $60.8 \%$, respectively). There was no significant difference $(\mathrm{P}>0.05)$ in nitrogen retention between pigs fed diet $\mathrm{B}$ and diet $\mathrm{C}$ (Table 7).

TABLE 7

Total apparent digestibility of crude protein and nitogen utilisation in growing male pigs

\begin{tabular}{lccc}
\hline & \multicolumn{3}{c}{ Diets } \\
\cline { 2 - 4 } & A & B & C \\
\hline Protein digestibility, \% & 82.3 & 83.9 & 83.6 \\
N intake, g/d & 51.6 & 51.6 & 52.2 \\
N retained /N intake, \% & $40.5^{\mathrm{b}}$ & $49.7^{\mathrm{a}}$ & $51.5^{\mathrm{a}}$ \\
$\quad$ /N digested, \% & $49.2^{\mathrm{b}}$ & $59.2^{\mathrm{a}}$ & $60.8^{\mathrm{a}}$ \\
\hline
\end{tabular}

means in the same row with different letters in their superscript differ significantly at $\mathrm{P}<0.05$

\section{DISCUSSION}

\section{Chemical composition of lupin seeds}

Seeds of yellow lupin contained a high level of crude protein. However, from pig nutrition point of view, mainly protein amino acid composition should be taken into consideration. Lupin seeds protein is characterized by a low methionine, tryptophan and lysine contents what classifies it as an unbalanced protein for non- 
ruminants. Similar amino acid profiles were reported for white and narrow-leaved lupins containing, however, less crude protein than seeds of yellow lupin varieties (Petterson and Mackintosh, 1994; Wasilewko and Buraczewska, 1999). Wasilewko and Buraczewska (1999) found negative correlation between protein level and NDF and ADF content in yellow lupin seeds. The level of crude fibre, NDF and $\mathrm{ADF}$ fractions was high in the tested seeds but in the range of values previously reported by Hill (1977) and Flis (1993). In general, lupin seeds contained more dietary fibre components than other leguminous seeds (Bach Knudsen, 1997). More comprehensive data on the composition of dietary fibre of lupin seeds were given by Gdala and Buraczewska (1996).

The lupin seeds used in the present study contained from 34 to $120 \mathrm{mg} / \mathrm{kg} \mathrm{DM}$ of manganese. As reported by Petterson and Mackintosh (1994), there are some differences in the content of the minor mineral elements in each lupin species. The manganese content in Australian varieties of L. angustifoilius ranged from 6 to 63 $\mathrm{mg} / \mathrm{kg}$ DM and in those of L. albus from 19 to $3800 \mathrm{mg} / \mathrm{kg}$ DM. In Polish varieties of L. angustifolius the manganese content was at the level of 26 to $58 \mathrm{mg} / \mathrm{kg} \mathrm{DM}$ and in $L$. albus varieties of 447 to $828 \mathrm{~g} / \mathrm{kg}$ DM (Wasilewko and Buraczewska, 1999). As reported by Zduńczyk and Flis (1997), mineral composition, including Mn level, depends more on environmental conditions of vegetation than on genetic differences among cultivars of lupins.

The nutritive value of lupin seeds may be seriously affected by their content of residual alkaloids. The alkaloid content in seeds of two tested lupins was 230 and $1300 \mathrm{mg} / \mathrm{kg}$ DM. The difference resulted from a high gramine content in Popiel lupin (Wasilewko et al., 1998). For comparison, the content of alkaloids in seeds of L. albus and L. angustifolius was from 600 to 950 and from 300 to $510 \mathrm{mg} / \mathrm{kg}$ DM, respectively (Wasilewko and Buraczewska, 1999). Christiansen et al. (1996) found correlation between the level of alkaloids and the rainfall during plant flowering; dry weather significantly increased the level of lupin alkaloids.

\section{Digestibility experiment}

Although lupin seeds contain a high level of non-starch polysaccharides (NSP) (Gdala and Buraczewska, 1996), the apparent ileal digestibility of their crude protein was similar as in varieties tested by Wünsche et al. (1990) amounting to $85 \%$ on an average and was as high as that of soyabean meal. The physiological effects of the NSP depend, however, on their composition and physico-chemical properties (Gdala, 1998). Lupin seeds contain high level of NDF, but the level of NDF bound protein is low. Jts value amounted to $2.9 \%$ of total crude protein content and was lower than these determined in pea and faba bean: 7.8 and $8.5 \%$, respectively (Gdala et al., 1998). Based on this, it can be concluded that availability of lupin protein is high. 
Among studied amino acids, threonine and tryptophan had the lowest digestibility up to the end of the small intestine. Knabe et al. (1989) testing 30 different feedstuffs also found the lowest threonine and tryptophan apparent ileal digestibility in pigs. It seems that the low digestibility of threonine may be explained by its high endogenous excretion into the lumen of the small intestine (Buraczewska, 1979).

The apparent ileal digestibility of isoleucine of lupin seeds was negatively correlated with the NDF content. In pea seeds, a negative correlation was found between the NDF content and the ileal digestibility of crude protein (Gdala et al., 1992).

The average true ileal digestibility of yellow lupin seeds was as high as $91 \%$. When compared with digestibility of other legume seeds (peas, faba beans), yellow lupin seeds had the highest true ileal digestibility in pigs (Maillard et al., 1990; Gdala et al., 1992; Rhodimet Nutrition Guide, 1993). The mean true ileal digestibility determined for two varieties of white lupin and three varieties of narrowleaved lupin was 87 and 90\%, respectively (Wasilewko, 1997).

\section{Balance experiment}

High total digestibility coefficients of crude protein were in the range of values reported by Augilera et al. (1985) when lupin-barley diets (L. albus var. Multolupa) were fed to growing pigs. Throughout the present experiment the lupin seed meal-barley diets were readily accepted by pigs and produced a mean daily gain of about $900 \mathrm{~g}$.

The amino acid profiles of seed protein of yellow lupin cultivars, like of other lupin species, showed deficiencies in lysine, methionine and tryptophan with respect to animal nutrition. As a consequence, pig and poultry diets containing lupins are frequently supplemented with crystalline amino acids. The present experiment confirmed earlier observations (Taverner, 1975; Leibholz, 1984) that the level of methionine in the total sulphur-containing amino acids plays an important role for animal growth. It was found that the nitrogen retention was lower in pigs fed diet $\mathrm{A}$ than in pigs fed diets $\mathrm{B}$ and $\mathrm{C}$. In diet $\mathrm{A}$ only $36 \%$ of the sulphurcontaining amino acids was provided by methionine, while in diet $\mathrm{B}$ and $\mathrm{C}$ methionine supplied about $50 \%$ of the sulphur-containing amino acid requirement of growing pigs. This is in agreement with earlier observation of Schutte et al. (1991) who suggested that at least $50 \%$ of the requirement of sulphur-containing amino acids of pigs (14-40 kg) should be covered by methionine. Liebholz (1984) showed a growth response in pigs $(21-35 \mathrm{~kg})$ to additional methionine $(0.2 \mathrm{~g} / \mathrm{kg})$ when lupin-seed meal was used as the sole supplement to a cereal based diet containing $3.0 \mathrm{~g} / \mathrm{kg}$ crystalline lysine. Similarly, lupin diet supplementation with a mixture of $2.25 \mathrm{~g} / \mathrm{kg} \mathrm{L}$-lysine $\cdot \mathrm{HCl}$ and $0.41 \mathrm{~g} / \mathrm{kg}$ methionine significantly improved the feed conversion ratio and increased, but not significantly, the rate of pig liveweight 
gains (Taverner, 1975). Methionine added to the lupin diet alone did not improve growth performance of pigs.

Protein and amino acids represent the most expensive proportion of pig and poultry diets. It is important, therefore, that they are used efficiently. Formulating diets on an ileal digestible amino acid basis is the method to achieve efficient use of protein (NRC, 1998). The present experimental results showed that the total amino acid content of the diets composed of good quality barley and yellow lupin seeds was adequate to cover, after supplementation with amino acids, the pig requirement for amino acids. However, when feedstuffs with high cystine and low methionine contents, i.e. lupin seeds, are used for pigs the requirement for methionine should also be considered.

\section{CONCLUSIONS}

Seeds of yellow lupins were characterized by a low variability in their chemical composition. Although yellow lupin seed contained a high level of non-starch polysaccharides, the apparent ileal digestibility of protein and amino acids was high. Similar performance can be achieved in pigs fed good quality barley-lupin diet supplemented within amino acids according to the pig requirement for either the total or the ileal digestible amino acid content.

\section{REFERENCES}

Agricultural Research Council (ARC), 1981. The Nutrient Requirements of Pigs. Commonwealth Agricultural Burcaux, Slough, UK

AOAC. 1990. Officials Methods of Analysis of the Association of Official Analytical Chemist. 15th Edition. Washington, DC

Aguilera J.F., Molina E., Prieto C., 1985. Digestibility and energy value of sweet lupin sced (Lupinus albus var. Multolupa) in pigs. Anim. Feed Sci. Technol. 12, 171-178

Bach Knudsen K.E., 1997. Carbohydrates and lignin contents of plant materials used in animal feeding. Anim. Feed Sci. Technol. 67, 319-338

Buraczewska L., 1979. Secretion of nitrogenous compounds in the small intestine of pigs. Acta physiol. pol. 30, 321-328

Buraczewska L., Buraczewski S., 1984. A note on determination of methionine and tryptophan. In: T. Żebrowska, L. Buraczewska, S. Buraczewski, J. Kowalczyk, B. Pastuszewska (Editors). Proceedings of the VIth International Symposium on Amino Acids, Serock (Poland). Polish Scientific Publishers, Warszawa, pp. 47-50

Eggum B.O., Tomes G., Beames R. M., Datta F.U., 1993. Protein and energy evaluation with rats of sceds from 11 lupin cultivars. Anim. Feed Sci. Technol. 43, 109-119

Flis M., 1993. Nutritive value of seeds of new faba bean and yellow lupin varieties for pigs (in Polish). Acta Acad. Agric. Tech. Olst., Zoot. 38, Suppl. A 
Gdala J., 1998. Composition, properties, and nutritive value of dietary fibre of legume seeds. A review. J. Anim. Feed Sci. 7, 131-149

Gdala J., Buraczewska L., 1996. Chemical composition and carbohydrate content of seeds from several lupin species. J. Anim. Feed Sci. 5, 403-416

Gdala J., Buraczewska L., Grala W., 1992. The chemical composition of different types and varieties of pea and the digestion of their protein in pigs. J. Anim. Feed Sci. 1, 71-79

Hill G.D., 1977. The composition and nutritive value of lupin seed. Nutr. Abstr. Rev., B 47, 511-529

Knabe D.A., LaRuc D.C., Gregg E.J., Martinez. G.M., Tanksley T.D. Jr., 1989. Apparent digestibility of nitrogen and amino acids in protein feedstuffs by growing pigs. J. Anim. Sci. 67, $441-458$

Leibholz J., 1984. A note on methionine supplementation of grower pig diets containing lupin-seed meal. Anim. Prod. 38, 515-517

Maillard R., Kiener T., Bertrand S., 1990. Digestible "REELLE", mesurée au niveau ileal des acides amines de la féverole et du lupin. Journées Rech. Porcine 22, 223-228

NRC, 1998. Nutrient Requirements of Swine. 10th Revised Edition. National Research Council, USA

Nutrient Requirements of Pigs. Nutritive Value of Feedstuffs (in Polish), 1993. The Kiclanowski Institute of Animal Physiology and Nutrition (Editor). Jabłonna (Poland)

Official Methods of Analysis of the Association of Official Analytical Chemists (AOAC), 1990. 15 Edition. Chapter 32. Washington, DC

Petterson D.S., Mackintosh J.B., 1994. The chemical composition of lupin seed grown in Australia. Proceedings of Australian Lupin Technical Symposium, Perth (Australia), pp. 49-57

Philips Scientific Atomic Absorption Data Book, 1988. Philips Scientific, England

Rhodimet Nutrition Guide, 1993. 2nd Eddition. Rhone Poulenc Animal Nutrition

Schutte J.B., Bosch M.W., De Jong J., Van Weerden E.J., Koch F., 1991. Factors affecting the requirement of dietary sulphur-containing amino acids of young pigs. Neth. J. Agric. Sci. 39, 91-101

Snedecor G.W., Cochran W.G., 1980. Statistical Methods. 7th Edition. The Iowa State University Press, Ames

Statgraphics Plus vr 7.0., 1993. Statistical Graphics System by Graphics Corporation

Taverner M.R., 1975. Sweet lupin seed meal as a protein source for growing pigs. Anim. Prod. 20, $413-419$

Van Lecuwen P., Jansman A.J.M., Van Kempen G.J.M., Verstegen M.W.A., Huisman J., 1991. The post valve T-caecum cannulation techique in pigs applicated to determine the digestibility of amino acids in maize, groundnut and sunflower meal. J. Anim. Physiol. Anim. Nutr. 65, 183-193

Van Soest P.J., 1973. Collaborative study of acid detergent fiber and lignin. J. Assoc. Agric. Chem. $56,781-782$

Van Soest P.J., Wine R.H., 1967. Use of detergents in the analysis of fibrous feeds. IV. Determination of plant cell wall constituents. J. Assoc. Agric. Chem. 50, 5I3-530

Wasilewko J., 1997. Chemical composition and nutritive value of new lupin varieties and the influence of the alkaloid level on feed intake and digestive processes in pigs. PhD Thesis. The Kielanowski Institute of Animal Physiology and Nutrition, Jabłonna (Poland)

Wasilewko J., Buraczewska L., 1999. Chemical composition including content of amino acids, minerals and alkaloids in seeds of three lupin species cultivated in Poland. J. Anim. Feed Sci. 8, $1-12$

Wasilewko J., Buraczewska L., Lechowski R., 1998. Is lupin gramine (indole alkaloid) an antinutritive factor for pigs? In: A.J.M. Jansman, G.D.Hill, J. Huisman, A.F.B.van der Poel (Editors). Procecdings of 3rd International Workshop on Antinutritional Factors in Legume Seeds and Rapeseed. Wageningen (The Netherlands), Wageningen Press, pp. 263-265 
Wünsche J., Henning U., Souffrant W.B., Kreienbring F., 1990. Untersuchungen zur präzäkalen Rohproteinverdaulichkeit und Aminosäurenresorption von Lupinen beim Schwein. Arch. Anim. Nutr. 40, 831-839

Wysocka W., Brukwicki T., Jałoszyński R., Hoffman K., 1989. A new and efficient method of extraction of alkaloids from lupin seeds. Lupin Lett. 13, 59-65

Zduńczyk Z., Flis M., 1997. Mincral composition of lupin seeds and biological effects of increased manganese level in animal diet (in Polish). Proceeding of the IVth Conference " $L$ ubin-BiałkoEkologia", Olsztyn (Poland), pp. 229-243

\section{STRESZCZENIE}

Oznaczanie strawności jelitowej aminokwasów lubinu i wykorzystanie tych wartości przy ukladaniu dawek pokarmowych

W doświadczeniu na rosnących wieprzkach oznaczono pozorną i rzeczywistą strawność jelitową białka i aminokwasów pięciu odmian łubinu żółtego. W doświadczeniu na młodych knurkach żywionych mieszanką jęczmienno-łubinową uzupełnioną syntetycznymi aminokwasami (lizyną, metioniną i tryptofanem) określono bilans azotu.

Strawność pozorna białka nasion łubinu oznaczona do końca jelita cienkicgo wynosiła od 81,9 do $84,9 \%$. Nie stwierdzono istotnych różnic w pozornej strawności białka i aminokwasów między badanymi odmianami łubinu żółtego. Strawność rzeczywista białka była wysoka i wynosiła od 87,5 do $90,5 \%$.

U zwierząt karmionych mieszanką uzupelnioną aminokwasami zgodnie z zapotrzcbowaniem na aminokwasy ogólne (metionina stanowiła $36 \%$ sumy aminokwasów siarkowych) retencja azotu była istotnie niższa $(\mathrm{P}<0.05)$ niż u zwierząt karmionych tą samą mieszanką z większą zawartością metioniny ( $50 \%$ sumy aminokwasów siarkowych) lub uzupełnioną aminokwasami zgodnie $z$ zapotrzebowaniem na aminokwasy strawne do końca jelita cienkiego. 